\title{
Theophylline Measurement
}

National Cancer Institute

\section{Source}

National Cancer Institute. Theophylline Measurement. NCI Thesaurus. Code C105445.

The determination of the amount of theophylline present in a sample. 